\title{
PENGARUH LINGKUNGAN KELUARGA DAN PENDIDIKAN TERHADAP MINAT WANITA UNTUK BERWIRAUSAHA DI DESA JINENGDALEM
}

\author{
Komang Melayani \\ Jurusan Pendidikan Ekonomi \\ Universitas Pendidikan Ganesha \\ Singaraja, Indonesia \\ e-mail : melachingu@gmail.com
}

\begin{abstract}
ABSTRAK
Penelitian ini bertujuan untuk mengetahui pengaruh: (1) lingkungan keluarga terhadap minat berwirausaha, (2) pendidikan terhadap minat berwirausaha, dan (3) pengaruh lingkungan keluarga dan pendidikan terhadap minat wanita untuk berwirausaha di Desa Jinegdalem. Penelitian ini termasuk dalam jenis penelitian kausal. Populasi dalam penelitian ini adalah wanita yang berwirausaha di Desa Jinengdalem yang berjumlah 320 orang, sedangkan sampel dalam penelitian ini berjumlah 100 orang. Data dikumpulkan dengan menggunakan kuesioner dan dianalisis menggunakan analisis regresi linier berganda dengan bantuan program statistical package for social sciences (SPSS) for windows versi 16. Hasil penelitian menunjukkan bahwa: (1) lingkungan keluarga berpengaruh signifikan terhadap minat berwirausaha ditunjukkan dari nilai thitung > ttabel $(11.900>1.660)$. (2) Pendidikan berpengaruh signifikan terhadap minat berwirausaha ditunjukkan dari nilai thitung > ttabel $(5.138>1.660)$. (3) Lingkungan keluarga dan pendidikan berpengaruh terhadap minat berwirausaha ditunjukkan dari nilai Fhitung > Ftabel $(143.882>3.09)$.

Kata kunci : lingkungan keluarga, pendidikan, minat berwirausaha

Abstract

This study aims to determine the effect of: (1) the interest of family environment toward entrepreneurship, (2) education toward entrepreneurship, and (3) the influence of family environment and education toward the interests of women to be entrepreneur in the Jinengdalem village. This study was a kind of causal research. The population in this study were entrepreneur woman in the Jinengdalem village that amount of 320 people, while the sample in this study were 100 people. Data were collected using a questionnaire and analyzed using multiple linear regression analysis with the help of the program statistical package for social sciences (SPSS) for Windows version 16. The results showed that: (1) a family environment significantly influence entrepreneurship interest shown from tcount $>$ $t$ table $(11,900>1,660)$. (2) Education significant effected on interest of entrepreneurship showed from tcount $>t$ table $(5138>1664)$. (3) Family environment and education affected the interest in entrepreneurship was shown on the value of Fcount $>F$ table (143 $882>$ 3.09).
\end{abstract}

Key words: family environment, education, entrepreneurship interest 


\section{PENDAHULUAN}

$\begin{array}{ccc}\text { Wirausaha } & \text { (entrepreneur) } & \text { adalah } \\ \text { orang yang berjiwa berani }\end{array}$ mengambil resiko untuk membuka usaha dalam berbagai kesempatan. Berjiwa berani mengambil resiko artinya bermental mandiri dan berani memulai usaha tanpa diliputi rasa takut atau cemas sekalipun dalam kondisi tidak pasti. Seorang wirausahawan dalam pikirannya selalu berusaha mencari, memanfaatkan, serta menciptakan peluang usaha yang selalu memberi keuntungan. "Jiwa kewirausahaan mendorong minat seseorang untuk mendirikan dan mengelola usaha secara maksimal" (Kasmir, 2009:15).

Slameto (2010: 180) menyatakan bahwa minat adalah suatu rasa lebih suka dan rasa ketertarikan pada suatu hal atau aktivitas, tanpa ada yang menyuruh. Sementara Syaiful Bahri Djamarah (2008: 132) mendefinisikan minat sebagai kecenderungan yang menetap untuk memperhatikan dan mengenang beberapa aktivitas. Seseorang yang berminat terhadap aktivitas akan memperhatikan aktivitas itu secara konsisten dengan rasa senang. Definisi minat pada penelitian ini akan dihubungkan dengan berwirausaha. Oleh karena itu pengertian berwirausaha tidak kalah pentingnya. Menurut Kasmir (2011: 19), wirausaha adalah orang yang berjiwa berani mengambil resiko untuk membuka usaha dalam berbagai kesempatan. Berjiwa berani mengambil resiko artinya bermental mandiri dan berani memulai usaha, tanpa diliputi rasa takut atau cemas sekalipun dalam kondisi tidak pasti. Joseph Schhumper dalam Buchari (2011: 24), mendefinisikan wirausaha adalah orang yang mendobrak system ekonomi yang ada dengan memperkenalkan barang atau jasa yang baru, dengan menciptakan bentuk organisasi baru atau mengolah bahan baku baru. Dari penjelasan minat dan wirausaha dapat ditarik kesimpulan bahwa minat berwirausaha adalah keinginan, ketertarikan, dan dorongan untuk berwirausaha dan melakukan segala sesuatu dengan perasaan senang, serta mampu menciptakan dan membuka usaha baru dengan keyakinan yang dimiliki dan dengan melihat kesempatan atau peluang yang ada tanpa merasa takut untuk mengambil resiko dalam berusaha meraih kesuksesan.

Menurut Kurnianti (2015) yang mempengaruhi minat secara garis besar dapat dikelompokkan menjadi faktor intrinsik dan faktor ekstrinsik. Faktor intrinsik adalah faktor-faktor yang timbul karena pengaruh rangsangan dari dalam individu itu sendiri. Faktor-faktor intrinsik sebagai pendorong minat berwirausaha antara lain karena adanya kebutuhan akan pendapatan, harga diri, dan perasaaan senang. Faktor ekstrinsik adalah faktor-faktor yang mempengaruhi individu karena pengaruh rangsangan dari luar. Faktor-faktor ekstrinsik yang mempengaruhi minat berwirausaha antara lain lingkungan keluarga, lingkungan masyarakat, peluang, pendidikan/ pengetahuan.

Lingkungan keluarga adalah kelompok masyarakat yang terkecil yang terdiri dari ayah, ibu, dan anak, dan anggota keluarga yang lain. Keluarga merupakan peletak dasar bagi pertumbuhan dan perkembangan anak, disinilah yang memberikan pengaruh awal terhadap terbentuknya kepribadian. Rasa tanggung jawab dan kreativitas dapat ditumbuhkan sedini mungkin sejak anak mulai berinteraksi dengan orang dewasa. Minat berwirausaha akan terbentuk apabila keluarga memeberikan pengaruh positif terhadap minat tersebut, karena sikap dan aktivitas sesama anggota keluarga saling mempengaruhi baik secara langsung maupun tidak langsung. (Edy Dwi Kurniati, 2015). Semakin kondusif lingkungan keluarga dan masyarakat disekitarnya, maka akan semakin mendorong seseorang untuk menjadi seorang wirausaha. Apabila lingkungan keluarga dan masyarakat mendukung maka seseorang akan semakin tinggi niatnya untuk menjadi wirausaha dibandingkan jika tidak memiliki dukungan dari lingkungan keluarga dan masyarakat (Suhartini, 2011). Buchari 
(2011: 8) mengungkapkan bahwa ada pengaruh dari orang tua yang bekerja sendiri, dan memiliki usaha sendiri memiliki kecenderung anaknya akan menjadi pengusaha pula. Keadaan ini seringkali memberi inspirasi pada anak sejak kecil. Anak yang memiliki orang tua seorang pengusaha atau hidup dalam lingkungan keluarga wirausahawan akan menerima pengetahuan pada masamasa awal sehingga membentuk sikap dan persepsi mengenai kepercayaan akan kemampuan berwirausaha.

Selain lingkungan keluarga pendidikan juga berperan penting sebagai pengarah bagi masa depan anaknya, sehingga secara tidak langsung juga dapat mempengaruhi minat terhadap pekerjaan bagi anak di masa yang akan datang, termasuk dalam hal berwirausaha. Pendidikan merupakan usaha sadar yang dilakukan oleh keluarga, masyarakat dan pemerintah melalui kegiatan bimbingan pengajaran dan pelatihan yang berlangsung di sekolah dan di luar sekolah sepanjang hayat untuk mempersiapkan peserta didik agar dapat memainkan peranan dalam berbagai lingkungan hidup secara tepat di masa yang akan datang. Pendidikan yang dimiliki seseorang memiliki pengaruh terhadap pengetahuan dan keahlian seseorang. (Redja Mudyaharjo 2012:11). Apabila pendidikan memadai maka seseorang akan siap untuk menjadi seorang wirausaha dan memimpin anak buahnya. Latar belakang pendidikan seseorang terutama yang terkait dengan bidang usaha, seperti bisnis dan manajemen atau ekonomi dipercaya akan mempengaruhi keinginan dan minatnya untuk memulai usaha baru di masa mendatang.

Berdasarkan hasil penelitian awal yang dilakukan di Desa Jinengdalem menunjukkan bahwa $12,39 \%$ mempunyai minat untuk berwirausaha sedangkan $87,61 \%$ kurang berminat untuk berwirausaha. Hal ini dapat dilihat dari jawaban yang diberikan oleh 10 orang responden yang menunjukkan bahwa tidak ada kesibukan dalam keluarga yang bermanfaat seperti kegiatan yang dapat menambah pengetahuan dan keterampilan bisnis, kegiatan yang memberi manfaat ekonomi untuk memenuhi kebutuhan anggota keluarga dan memberi bekal hidup di masa depan. Tidak adanya persiapan mental berwirausaha dalam lingkungan keluarga, seperti anak tidak dididik untuk optimis dalam menghadapi masalah kehidupan atau rintangan, tidak adanya peraturan kepada anak untuk disiplin waktu dalam hal belajar dan bermain, dan orang tuanya masih kurang dalam mendidik anak untuk tidak mengandalkan orang lain dalam menyelesaikan pekerjaan dan bertanggung jawab terhadap tugas atau pekerjaan yang diberikan.

Selain permasalahan yang ditemukan di lingkungan keluarga, dalam hal pendidikan juga mengalami masalah diantaranya masih banyak orang yang beranggapan bahwa kemampuan pendidikan masih ada batasnya. Sekolah terbatas kemampuannya dalam mewujudkan pribadi manusia wirausaha oleh karena pertama, sekolah menghadapi anakanak yang dasar-dasar perkembangan pribadi mereka telah terbentuk dari lingkungan keluarga. Kedua, antara sekolah dan keluarga sering terdapat perbedaan atau konflik pendapat dan keinginan mengenai masa depan anak. Ketiga, sekolah mengemban misi yang cukup berat, karena disamping diberi kepercayaan dari pihak keluarga untuk memberikan bekal hidup pribadi anak juga mengemban misi dari pemerintah atau negara untuk mempersiapkan anak didik itu untuk dapat menjadi warga masyarakat dan warga negara yang baik.

Berdasarkan alasan tersebut, maka penulis ingin melakukan penelitian dengan judul : "Pengaruh Lingkungan Keluarga Dan Pendidikan Terhadap Minat Wanita Untuk Berwirausaha di Desa Jinengdalem"

\section{METODE}

Penelitian ini merupakan jenis penelitian kausalitas. Penelitian ini 
bertujuan untuk mengetahui pengaruh dari variabel bebas terhadap variabel terikat. Adapun yang menjadi variabel bebas dalam penelitian ini adalah lingkungan keluarga dan pendidikan sedangkan variabel terikatnya adalah minat berwirausaha. Hasil yang diharapkan dalam penelitian ini yaitu dapat mengetahui seberapa besar lingkungan keluarga dan pendidikan berpengaruh terhadap minat wanita untuk berwirausaha di Desa Jinengdalem.

Berdasarkan data yang didapat jumlah wanita yang ada di Desa Jinengdalem sebanyak 2.582 orang. Dari jumlah wanita di Desa Jinengdalem, wanita yang bekerja sebagai wirausaha sebanyak 320 orang. Jadi populasi dalam penelitian ini adalah wanita yang berwirausaha di Desa Jinengdalem sebanyak 320 orang. Teknik pengambilan sampel yang digunakan dalam penelitian ini adalah Purposive Sampling, yaitu teknik mengambil sampel secara sengaja dan telah sesuai dengan semua persyaratan sampel yang diperlukan. Untuk menentukan jumlah sampel dari populasi digunakan rumus Slovin (Umar Husein, 2005:78) sehingga jumlah sampel pada penelitian ini sebanyak 100 orang.
Jenis data yang digunakan dalam penelitian ini adalah data kuantitatif dan sumber data yang digunakan yaitu data primer dan sekunder. Metode pengumpulan data dalam penelitian ini adalah menggunakan angket atau kuesioner. Penyebaran kuesioner ini dilakukan secara langsung dengan memberikan kuesioner yang berisi daftar pertanyaan yang telah disusun kepada responden yaitu wanita wirausaha di Desa Jinengdalem. Penelitian ini menggunakan intrumen berupa kuesioner. Skala yang digunakan dalam penyusunan kuesioner adalah Skala Likert dengan satuan ukur ordinal. Penelitian ini menggunakan teknik analisis data yaitu regresi linier berganda untuk mengetahui pengaruh variabel bebas $(X)$ terhadap variabel terikat (Y) melalui program komputer SPSS 16 dan melakukan uji asumsi klasik

\section{HASIL DAN PEMBAHASAN \\ Hasil}

Berdasarkan perhitungan analisis data, pengaruh lingkungan keluarga terhadap minat wanita untuk berwirausaha di Desa Jinengdalem dapat dilihat pada tabel

\begin{tabular}{|c|c|c|c|c|c|c|}
\hline \multicolumn{7}{|c|}{ Tabel 1. Hasil Uji T Untuk Variabel Lingkungan Keluarga } \\
\hline \multirow[b]{2}{*}{ Model } & & \multicolumn{2}{|c|}{ Unstandardized Coefficients } & \multicolumn{2}{|c|}{$\begin{array}{l}\text { Standardized } \\
\text { Coefficients }\end{array}$} & \multirow[b]{2}{*}{ Sig. } \\
\hline & & $\mathrm{B}$ & Std. Error & Beta & $\mathrm{t}$ & \\
\hline \multirow[t]{2}{*}{1} & (Constant) - & -8.035 & 3.904 & & -2.058 & .042 \\
\hline & $\begin{array}{l}\text { Lingkungan } \\
\text { Keluarga }\end{array}$ & .816 & .069 & .686 & 11.900 & .000 \\
\hline $\begin{array}{l}\text { Berda } \\
\text { menunjukkan } \\
\text { lingkungan } \\
\text { signifikan } \\
\text { berwirausaha } \\
11.900>\text { ttab }\end{array}$ & $\begin{array}{l}\text { bahwa } \\
\text { keluarga } \\
\text { terhadap } \\
\text { karena nila } \\
=1.664 \text { a } \\
=0.05 \text { maka }\end{array}$ & $\begin{array}{l}\text { tabe } \\
\text { berpen } \\
\text { lai thitu } \\
\text { atau } p \text {. }\end{array}$ & & \multicolumn{3}{|c|}{$\begin{array}{l}\text { lingkungan keluarga memiliki pengaruh } \\
\text { yang signifikan terhadap terhadap } \\
\text { minat wanita untuk berwirausaha di } \\
\text { Desa Jinengdalem. } \\
\text { Pengaruh pendidikan terhadap } \\
\text { minat wanita untuk berwirausaha di desa } \\
\text { jinengdalem dapat dilihat pada tabel } 2 \text {. }\end{array}$} \\
\hline
\end{tabular}

Oleh karena itu, maka dapat disimpulkan bahwa variabel 


\begin{tabular}{llllll}
\hline \multicolumn{7}{c}{ Tabel 2. Hasill Ujit untuk Variabel Pendidikan } \\
\hline
\end{tabular}

Berdasarkan tabel 2 menunjukkan bahwa variabel pendidikan berpengaruh signifikan terhadap minat berwirausaha, karena nilai thitung $=5.138>$ tabel $=1.664$ atau $p$-value $=0.000<\alpha=0.05$ maka HO ditolak. Oleh karena itu, maka dapat disimpulkan bahwa variabel pendidikan berpengaruh secara signifikan terhadap minat wanita untuk berwirausaha di Desa Jinengdalem.

Pengaruh Lingkungan Keluarga Dan Pendidikan Terhadap Minat Wanita Untuk Berwirausaha Di Desa Jinengdalem dapat dilihat pada tabel 3.

Tabel 3. Hasil Perhitungan Uji F

\begin{tabular}{|ll|r|r|r|r|r|}
\hline Model & & $\begin{array}{c}\text { Sum of } \\
\text { Squares }\end{array}$ & Df & Mean Square & F & Sig. \\
\cline { 2 - 7 } 1 & Regression & 5502.161 & 2 & 2751.081 & 143.882 & .000 a \\
& Residual & 1854.679 & 97 & 19.120 & & \\
& Total & 7356.840 & 99 & & & \\
\hline
\end{tabular}

Berdasarkan tabel 3 menunjukkan bahwa Fhitung = $143.882>$ Ftabel $=3.12$ atau $p$-value $=$ $0.000<\alpha=0,05$ hal ini berarti $\mathrm{HO}$ ditolak. Oleh karena itu, maka dapat disimpulkan bahwa variabel lingkungan keluarga dan pendidikan memiliki pengaruh yang signifikan terhadap variabel minat wanita untuk berwirausaha di Desa Jinengdalem.
Untuk mengetahui besarnya pengaruh lingkungan keluarga dan pendidikan terhadap minat berwirausaha, maka dapat digunakan analisis koefisien determinasi (Adjusted $R$ Square). Besarnya koefisien determinasi (Adjusted $R$ Square) dapat dilihat pada tabel 4 .

\begin{tabular}{|c|c|c|c|c|}
\hline \multicolumn{5}{|c|}{$\begin{array}{l}\text { Tabel 4. Hasil Perhitungan Koefisien Determinasi } \\
\text { (Adjusted Rsquare) }\end{array}$} \\
\hline Model & $\mathrm{R}$ & R Square & $\begin{array}{l}\text { Adjusted R } \\
\text { Square }\end{array}$ & $\begin{array}{l}\text { Std. Error of } \\
\text { the Estimate }\end{array}$ \\
\hline 1 & $.865^{a}$ & .748 & .743 & 4.37269 \\
\hline
\end{tabular}

Berdasarkan hasil analisis pada tabel 4 dengan menggunakan program SPSS 16.0 for windows menunjukkan bahwa besarnya pengaruh variabel lingkungan keluarga dan pendidikan terhadap variabel minat berwirausaha sebesar 0,743 sehingga sumbangan pengaruh untuk variabel lingkungan keluarga (X1) dan pendidikan (X2) terhadap minat berwirausaha (Y) adalah sebesar $74,3 \%$. Hal ini berarti minat wanita untuk berwirausaha di Desa Jinengdalem sebesar 74,3\% dipengaruhi oleh variabel lingkungan keluarga dan pendidikan, sedangkan sisanya sebesar $25,7 \%$ dipengaruhi oleh faktor lain yang tidak termasuk 
dalam penelitian ini.

Berdasarkan hasil analisis

untuk berwirausaha di Desa Jinengdalem digunakan nilai data, untuk mengetahui persamaan regresi pengaruh lingkungan keluarga dan pendidikan terhadap minat wanita Unstandardized Coefficients Beta dapat dilihat pada tabel

5.

Tabel 5. Hasil Uji t untuk Variabel Pendidikan

\begin{tabular}{|c|c|c|c|c|c|c|}
\hline \multirow{2}{*}{\multicolumn{2}{|c|}{ Model }} & \multicolumn{2}{|c|}{$\begin{array}{l}\text { Unstandardized } \\
\text { Coefficients }\end{array}$} & \multirow{2}{*}{$\begin{array}{c}\text { Standardized } \\
\text { Coefficients } \\
\text { Beta }\end{array}$} & \multirow[b]{2}{*}{$\mathrm{t}$} & \multirow[b]{2}{*}{ Sig. } \\
\hline & & $\mathrm{B}$ & Std. Error & & & \\
\hline \multirow[t]{3}{*}{1} & (Constant) & -8.035 & 3.904 & & -2.058 & .042 \\
\hline & $\begin{array}{l}\text { Lingkungan } \\
\text { Keluarga }\end{array}$ & .816 & .069 & .686 & 11.900 & .000 \\
\hline & Pendidikan & .491 & .096 & .296 & 5.138 & .000 \\
\hline
\end{tabular}

Berdasarkan hasil analisis pada

tabel 5 dengan mengunakan program SPSS 16.0 for windows dapat dibuat persamaan garis regresi. Persamaan garis regresi yang dapat dibuat untuk menggambarkan pengaruh lingkungan keluarga dan pendidikan terhadap minat berwirausaha adalah sebagai berikut.

$\hat{Y}=-8.035+0.816 X_{1}+0.491 X_{2}$

Keterangan:

$\hat{Y}=$ Minat Berwirausaha

$\mathrm{X}_{1}=$ Lingkungan Keluarga

$\mathrm{X}_{2}=$ Pendidikan

Interpretasi dari model regresi di atas adalah sebagai berikut.

1. Konstanta -8.035 menunjukkan bahwa jika variabel bebas lingkungan keluarga (X1) dan pendidikan (X2) sama dengan nol, maka minat berwirausaha $(Y)$ akan mengalami kenaikan sebesar 8.035 satuan.

2. Koefisien regresi 0.816 berarti jika variabel lingkungan keluarga (X1) meningkat tiap satu satuan, maka minat berwirausaha $(Y)$ akan mengalami peningkatan sebesar 0.816 dengan syarat variabel bebas lainnya tetap.

3. Koefisien regresi 0.491 berarti jika variabel pendidikan (X2) meningkat tiap satu satuan, maka minat berwirausaha $(Y)$ akan mengalami peningkatan sebesar 0.491 dengan syarat variabel bebas lainnya tetap.

Berdasarkan persamaan

regresi linier berganda yang dihasilkan, dapat ditunjukkan bahwa lingkungan keluarga dan pendidikan berpengaruh positif terhadap minat wanita untuk berwirausaha di Desa Jinengdalem.

\section{PEMBAHASAN}

Berdasarkan hasil penelitian yang dilakukan mengenai pengaruh lingkungan keluarga dan pendidikan terhadap minat wanita untuk berwirausaha di Desa Jinengdalem diketahui bahwa lingkungan keluarga dan pendidikan secara simultan memiliki pengaruh terhadap minat wanita untuk berwirausaha di Desa Jinengdalem. Temuan ini mendukung teori yang dikemukakan oleh Kurnianti (2015) yang menyatakan bahwa minat secara garis besar di pengaruhi oleh faktor intrinsik (kebutuhan akan pendapatan, harga diri, dan perasaaan senang) dan faktor ekstrinsik (lingkungan keluarga, lingkungan masyarakat, peluang, pendidikan atau pengetahuan).

Hasil temuan ini menunjukkan bahwa variabel lingkungan keluarga memiliki pengaruh yang signifikan terhadap minat wanita untuk berwirausaha di Desa Jinengdalem. Keluarga yang sejak kecil telah memperkenalkan anak dengan dunia wirausaha akan memberikan dampak kepada anak untuk tertarik dan terjun dalam dunia wirausaha. Lingkungan keluarga yang berasal dari keluarga wirausaha akan lebih mempermudah anak untuk terjun dalam dunia 
wirausaha, hal ini dikarenakan anak telah mendapat contoh secara langsung sejak ia masih kecil, adanya fasilitas keluarga juga mempermudah langkah anak untuk terjun dalam dunia wirausaha. Hasil penelitian ini sejalan dengan teorinya Buchari Alma (2013: 8) yang mengungkapkan bahwa ada pengaruh dari orang tua yang bekerja sendiri, dan memiliki usaha sendiri cenderung anaknya jadi pengusaha pula. Hasil penelitian ini juga mendukung teorinya Wasty Soemanto (2008) yang menyatakan bahwa lingkungan keluarga merupakan salah satu tempat pelaksanaan pendidikan kewirausahaan selain lingkungan sekolah dan masyarakat. Temuan ini juga sejalan dengan penelitian yang dilakukan oleh Ary Widyaningsih yang menyatakan bahwa lingkungan keluarga dan motivasi berwirausaha berpengaruh positif terhadap minat berwirausaha.

Selain lingkungan keluarga pendidikan juga memiliki pengaruh yang signifikan terhadap minat berwirausaha. Dalam berwirausaha tidak lepas dari pendidikan atau pelatihan wirausaha yang diterima seseorang. Pendidikan dan keahlian yang wanita miliki dapat mempengaruhi dalam memilih kegiatankegiatan ekonomi yang bisa ditekuninya. Dapat diduga bahwa wanita dengan pendidikan yang lebih baik dapat menseleksi kegiatan-kegiatan ekonomi yang lebih baik pula dibandingkan dengan wanita yang kurang berpendidikan. Dengan adanya pendidikan akan mendorong seseorang untuk memiliki pemahaman berwirausaha dan dengan pemahaman berwirausaha ini, seseorang akan memiliki minat berwirausaha. Hasil penelitian ini mendukung teori dari Buchari Alma (2009) yang menyatakan bahwa latar belakang timbulnya minat berwirausaha adalah lingkungan keluarga, pendidikan, nilai-nilai (Values) personal, usia dan riwayat pekerjaan. Temuan ini juga sejalan dengan penelitian yang dilakukan sinha (1996) yang menyatakan apabila pendidikan memadai maka seseorang akan siap untuk menjadi seorang wirausaha dan memimpin anak buahnya. Latar belakang pendidikan seseorang terutama yang terkait dengan bidang usaha, seperti bisnis dan manajemen atau ekonomi dipercaya akan mempengaruhi keinginan dan minatnya untuk memulai usaha baru di masa mendatang.

\section{Simpulan dan saran \\ Simpulan}

Berdasarkan hasil penelitian dan pembahasan, maka dapat disimpulkan sebagai berikut.

1. Lingkungan keluarga berpengaruh signifikan secara parsial terhadap minat wanita untuk berwirausaha di Desa Jinengdalem. Hal tersebut di tunjukkan dari hasil analisis ttes yang menunjukkan bahwa nilai thitung $=11.900>$ tabel $=1.664$ atau $p$-value $=0.000<\alpha=0.05$.

2. Pendidikan berpengaruh signifikan secara parsial terhadap minat wanita untuk berwirausaha di Desa Jinengdalem. Hal tersebut di tunjukkan dari hasil analisis ttes yang menunjukkan bahwa nilai thitung $=5.138>$ ttabel $=1.664$ atau $p$-value $=0.000<\alpha=0.05$.

3. Lingkungan keluarga dan pendidikan berpengaruh signifikan secara parsial terhadap minat wanita untuk berwirausaha di Desa Jinengdalem. Hal tersebut di tunjukkan dari hasil analisis Ftes yang menunjukkan bahwa nilai bahwa Fhitung $=143.882>$ Ftabel $=3.12$ atau $p$-value $=0.000<\alpha=$ 0,05 . Besarnya pengaruh secara simultan dari variabel lingkungan keluarga dan pendidikan terhadap minat berwirausaha adalah sebesar $74,3 \%$ sedangkan sisanya sebesar $25,7 \%$ dipengaruhi oleh faktor lain yang tidak termasuk dalam penelitian ini.

\section{Saran}

Berdasarkan simpulan di atas,
maka dapat dikemukakan $\begin{array}{r}\text { saran } \\ \text { berikut. }\end{array}$


1. Untuk meningkatkan minat berwirausaha perlu adanya dorongan dan motivasi dari pihak keluarga. Pihak keluarga terutama orang tua harus mendidik anaknya menjadi anak yang mandiri, kreatif, bertanggung jawab dan memiliki jiwa kepemimpinan sehingga dapat ditumbuhkan minat berwirausaha pada anak.

2. Pada pendidikan formal dan non formal agar memberikan pelayanan serta fasilitas yang maksimal dalam menunjang kemampuan anak sehingga pengetahuan atau keterampilan tersebut dapat dipergunakan dengan baik.

3. Bagi wanita yang berwirausaha dapat membagikan pengalamannya kepada wanita lainnya sehingga mereka terinspirasi dan berkeinginan untuk menjadi wirausahawan.

4. Bagi peneliti lain yang bermaksud melakukan penelitian di bidang minat berwirausaha khususnya yang tertarik dan berminat untuk mendalami tentang lingkungan keluarga dan pendidikan, diharapkan untuk mengembangkan penelitian ini dengan menambah sampel atau populasi yang lebih luas agar dapat menguji variabel lain yang diduga kuat dapat mempengaruhi minat berwirausaha.

\section{DAFTAR PUSTAKA}

Arikunto, Suharsimi. 2005. Manajemen Penelitian. Jakarta: Rineka Cipta.

2006. Prosedur Penelitian Suatu Pendekatan Praktek. Adisi Revisi VI. Jakarta: Rineka Cipta.

2009. Dasar-dasar Evaluasi Pendidikan. Jakarta : PT. Bumi Aksara

$2010 . \quad$ Prosedur Penelitian:Suatu pendekatan praktek. Jakarta :Rineka Cipta.

Alma, Buchari. 2004. Kewirausahaan Penuntun Perkuliahan untuk Perguruan Tinggi. Bandung: Alfabeta.

\section{Kewirausahaan. Bandung :} Alfabeta

2011. Kewirausahaan. Bandung: Alfabeta.

Ary Widyaningsih. 2015. Pengaruh Lingkungan Keluarga dan Motivasi Berwirausaha Terhadap Minat Berwirausaha Mahasiswa Program Studi Pendidikan Administrasi Perkantoran Fakultas Ekonomi UNY.(Tidak Diterbitkan). Jurusan Pendidikan Administrasi. Fakultas Ekonomi. Universitas Negeri Yogyakarta

Bygrave, W. D. 2003. The Portable MBA Entrepreneurship. Jakarta: Binarupa Aksara.

Bob dan Anik Anwar. 1983. Pedoman Pelaksanaan Menuju Pra Seleksi Murni. Bandung: Ganesa Exact.

Caryanti, Demi. 2009. Pengaruh Latar Belakang Pendidikan Dan Tingkat Pendapatan Orang Tua Terhadap Minat Berwirausaha Siswa SMK Negeri 1 Sukasada Tahun Ajaran 2008/2009. Skripsi (Tidak Diteribitkan).Jurusan Pendidikan Ekonomi.Fakultas IImu Sosial Undiksha.

\footnotetext{
Departemen Pendidikan dan kebudayaan/Pusat Bahasa. 2001. Kamus Besar Bahasa Indonesia (Edisi ke-3). Jakarta: Balai Pustaka.

Dhiah, Erlita. 2007. Faktor-Faktor Yang Mempengaruhi Minat
} 
p-ISSN : 2599-1418

e-ISSN : 2599-1426

Berwiraswasta

(Studi

Deskriptif Pada Usahawan

Rental Komputer Di Sekaran

Gunung Pati Semarang).

Skripsi (Tidak Diterbitkan).

Fakultas IImu Sosial

Universitas Negeri Semarang.

Djamarah, Syaiful Bahri. 2008. Psikologi

Belajar. Jakarta : Rineka Cipta

. 2010. Psikologi Belajar. Jakarta : PT. Rineka Cipta.

\begin{tabular}{|c|c|}
\hline dang & $\begin{array}{l}\text { dan Nuryata. } \\
\text { Kewirausahaan Di } \\
\text { Jakarta:Sekarmita }\end{array}$ \\
\hline hozali, & $\begin{array}{lr}\quad \text { Imam.2006. } & \begin{array}{r}\text { Aplikasi } \\
\text { Analisis }\end{array} \\
\text { Analivarite } \\
\text { dengan SPSS, Cetakan } \\
\text { keempat, PT. Raja } \\
\text { Grafindo } \\
\text { Jakarta }\end{array}$ \\
\hline & $\begin{array}{l}\text { 2011. Aplikasi Analis } \\
\text { Multivariate } \\
\text { Program IMB SPSS } 1 \\
\text { Edisi Kelima. Semarang } \\
\text { Universitas Diponogoro. }\end{array}$ \\
\hline
\end{tabular}

Hendro. 2011. Dasar-Dasar Kewirausahaan. Jakarta: Erlangga

Kasmir. 2009. Kewirausahaan. Jakarta : Penerbit PT. Raja Grafindo

2011. Kewirausahaan. Jakarta :PT. Raja Grafindo

Kurnianti, Edy Dwi. 2015. Kewirausahaan Industri. Yogyakarta: Depublish.

Lieli, Suharti dan Sirine Hani. 2011. Faktor-Faktor Yang Berpengaruh terhadap Niat Kewirausahaan

(Entrepreneurial Intention). Jurnal Manajemen dan Kewirausahaan. Vol.13, No. 2, pp. 124-134.
Jurnal Pendidikan Ekonomi Undiksha Volume 9 No.1 Tahun: 2017

Lestari, B.R dan Trisnadi Wijaya. 2012. Pengaruh Pendidikan Kewirausahaan terhadap Minat Berwirausaha Mahasiswa di STIE MDP, STMIK MDP, Dan STIE MUSI. Forum Bisnis dan Kewirausahaan Jurnal IImiah STIE MDP. Vol. 1 No. 02, pp: 112-119.

Muchammad Arif Mustofa. 2014. "Pengaruh Pengetahuan Kewirausahaan, Self Efficacy dan Karakter Wirausaha Terhadap Minat Berwirausaha".

Mahmud, Dwimyati. 2008. Pengertian Minat Tersedia pada http://belajarpsikologi.com/pe ngertianminat.

Maman Suryamannim. 2006. Minat Berwirausaha pada Mahasiswa Pendidikan Teknik Elektro. Skripsi. FT-UNS.

Manihai, Roy. 2009. Konsep Lingkungan Keluarga Menurut Para Ahli. Tersedia pada http://aroxxkaluwutu.blogspot. com/2013/06/konseplingkungan.keluargamenurutp ara.html. (diakses tanggal 20 Juni 2016).

Matonda, Indra Hakim. 2006. Analisis Faktor-faktor yang Mendorong Wirausahawan Memulai Usaha Baru (Studi Pada Gerai Handphone Jalan Letda Sujono Medan). Medan : Perpustakaan Ekonomi USU. (Tidak Dipublikasikan)

Patria, Paulus Adhitama. 2014. FaktorFaktor Yang Mempengaruhi Minat Berwirausaha (Studi Kasus Mahasiswa Fakultas Ekonomika Dan Bisnis UNDIP. Skripsi (tidak diterbitkan). Jurusan IESP Semarang. 
p-ISSN : 2599-1418

e-ISSN : 2599-1426

Rano, Aditia Putra. 2012. "Faktor-faktor Penentu Minat Mahasiswa Manajemen Untuk Berwirausaha". Jurnal. Universitas Negeri Padang.

Redja, Mudyaharjo. (2012). Pengantar Pendidikan. Jakarta: PT. Rajagrafindo Persada.

Retno, Budi Lestari dan Trisnandi Wijaya. 2012. Pengaruh Pendidikan Kewirausahaan Terhadap Minat Berwirausaha Mahasiswa di STIE MDP,STMK MDP, dan STIE MUSI. Jurnal. STIE MDP.

Santoso. 2009. Lingkungan Tempat Tinggal Menentukan Minat Berwirausaha. FKIP.UNS (Laporan Penelitian). Surakarta : UNS

Serian, Wijayanto. (2009). Pengantar Entrepreneursip. Jakarta: Grasindo.

Sirod Hantoro, (2005). Kiat Sukses Berwirausaha.Yogyakarta: Adicita Karya Nusa.

Sitepu, Erin Karina. 2008. Analisis Faktor - faktor yang Menghambat Women Entrepreneur Dalam Berwirausaha (Studi Kasus Pada Wanita Pengusaha Salon Di Jalan Sei Mencirim Medan). Medan Perpustakaan Ekonomi USU. (Tidak Dipublikasikan).

Slameto. 2010. Belajar dan FaktorFaktor yang Mempengaruhinya. Jakarta : PT. Rineka Cipta.

Soemanto, Wasty. 2006. Pendidikan Wiraswasta. Jakarta: Bumi Aksara.

2008. Pendidikan Wiraswasta. Jakarta: Bumi Aksara.

Soekanto, Soerjono. 2004. Sosiologi Keluarga. Jakarta: PT Rineka Cipta
Jurnal Pendidikan Ekonomi Undiksha

Volume 9 No.1 Tahun: 2017

Sugiyono. 2010. Metode Penelitian Bisnis. Bandung : CV Alfabeta. 2012. Statistika untuk
Penelitian.
ALFABETA.

Sugihartono dkk. 2007.Psikologi Pendidikan.Yogyakarta:UNY Press

Suharyadi, dkk. 2007. Kewirausahaan.Jakarta: Salemba Empat

Suharti, L \& Sirine, H. 2011. "Faktorfaktor yang Berpengaruh terhadap Niat (Studi terhadap Mahasiswa Universitas Kristen Satya Wacana Salatiga)". Jurnal Manajemen dan Kewirausahaan.

Sukardi. 2000. Pengantar Pelaksanaan Program Bimbingan dan Konseling di Sekolah. Jakarta: Rineka Cipta.

Suryana. 2006. Kewirausahaan: Pedoman Praktis ; Kiat dan Proses Menuju Sukses. Jakarta: Penerbit Salemba Empat.

2008. Kewirausahaan Pedoman Praktis, Kiat dan Proses Menuju Sukses. Jakarta: Salemba Empat.

\begin{tabular}{lr}
\multicolumn{1}{c}{2011.} & Kewirausahaan \\
Pendekatan & Karakteristik \\
Wirausahawan & Sukses. \\
Jakarta: Kencana. &
\end{tabular}

Sutanto, Adi. 2002. Kewiraswastaan. Jakarta: Ghalia Indonesia.

Utin Nina Hermina, dkk. (2011). Pengaruh Mata Kuliah Kewirausahaan Terhadap Minat Mahasiswa Menjadi Wirausaha Pada Program Studi Administrasi Bisnis Politeknik Negeri Pontianak. Jurnal 
Winkel, W. S. (2004). Psikologi Pengajaran. Yogyakarta: Media Abadi.

Wibowo, Agus. 2011. Pendidikan Kewirausahaan. Jakarta: Pustaka Pelajar.

Yati, Suhartini. 2011. "Analisis FaktorFaktor Yang Mempengaruhi Minat Mahasiswa Dalam Berwirausaha". Jurnal. Universitas PGRI Yogyakarta.

Yogi, Herdani, (2010). Kewirausahaan Sebagai Solusi Pengangguran Pemuda di Indonesia. Artikel. Diakses dari http://www.dikti.go.id/index.ph p?option=com content\&view =article\&id=1549:kewirausah aan-sebagai-solusipengangguran-pemuda-diindonesia \&catid=159:artikelkontributor

Yusuf, Syamsu. 2012. Perkembangan Peserta Didik. Jakarta: PT Raja Grafindo Persada.

Zimmerer, Thomas dan Norman M. Scarborough. 2008. Kewirausahaan dan Manajemen Usaha Kecil. Jakarta : Penerbit Salemba Empat 